\title{
貯水池の堆砂問題について \\ ON THE SEDIMENT PROBLEMS OF RESERVOIRS
}

$\begin{array}{llr}\text { 吉 } & \text { 良 } 八 \text { 郎* } \\ \text { By } & \text { Hachiro } & \text { Kira }\end{array}$

\section{1. まえがき}

河川開発のため, 治水・利水目的のダムが河道に築造 されると, 人為的または自然的な環境変化により新しい つりあい関係を得るため河道全体の形態を変え, その上 流側では dam up によって河川流況が変化し堆砂現象 が起こる。この堆砂現象は, 一応砂防効果や骨材資源の 積極的活用面から多少の効用をもたらすものであるが， 貯水容量を減少させ, かんがい・発電・上水道または洪 水調節など本来の治水・利水目的である貯水機能を低下 喪失させ, 堆砂の進展に伴ってダム付属構造物の機能障 害を誘起する。また貯水池上流側では, 河床上昇, 洪水位 上昇をたは地下水位上昇現象を誘起し, 冠水・排水不良 区域の拡大による内水災害や池岸地山の崩壊・地すべり など土砂災害の多発激甚化の原因となることもある。特 に最近は, これら背砂上昇に伴う洪水障害が社会問題と して取り上げられるようになり，ダム計画の前途に大き な障壁となってきた。わが国は, 地形急しゅんであり, 地盤運動が激しく, かつ台風常襲地で降水量が多いため 河川の流出土砂量がきわめて多く, 他方, 自然の地形的 条件がダム計画面からみて極度に劣っており, 欧米の主 要貯水池群に比較して一般にその規模・貯水能 (たとえ ば $C / F$ 比や $C / I$ 比) が小さく, 経済効果の面できわめ て不利であるとされている。したがって，ダムの堆砂災 害もきわめて梁刻な様相を呈してきており，平均して貯 水容量の約 $2 \%$ 近くが年々堆砂で減少している 現状か らみて, 今後ますます堆砂現象に基づいた諸災害の傾向 は増大するものと考えられる。

他方, ダムの下流区域では, 堆砂現象による流砂のし や断, 河川流量の変化, または流下水勢による洗掘や選 別掃砂などによって，一般に河床は低下し，次第に粗砂 れきでおおわれる armoring 効果 (armor coat の生成)

* 正会員 農博 香川大学教授 農学部農業工学科
を呈するに至る。このダムによる土砂扞止作用に基づい た河床低下は, 河川構造物の浮き上がりによる損傷, 農 業用水の取水困難や河床埋設利水施設の露出・損傷, 堤 内地の地下水位低下による井戸取水困難, 堤内地加ら河 川への逆漏水, または海岸侵食の助長など, 多くの治 水・利水機能の諸障害を誘起するものである。

以上の観点から, ダム堆砂問題の解明は防災計画の面 からみて重要度がきわめて高いが，他方ダム計画の技術 面からみても, ダムの耐用年数や有効貯水量の評価, 放 水・取水施設の配置, ダム安定計算に掞ける堆砂圧の考 慮などの点から, 適正な設計堆砂量（または設計比堆砂 量) や堆砂分布形状などの推算がぜひ必要になってく る。

このようなダム堆砂問題を合理的に解決するために は，まず堆砂現象の実態を客観的に正しく把握する必要 があり，貯水池に流入する土砂量や堆砂分布形状など堆 砂機構の究明が先決であり,さらに進んで堆砂防除対策 の確立が必要となってくる。この点, 近年わが国はもと より国際的にも国際大ダム会議, 国際かんがい排水会議 または国際水理学会などの主要課題として取り上げら れ, 土砂水理学の発展に伴って数多くの研究がなされ, 種々の特性が明らかにされてきた。

筆者も約 10 数年前加ら貯水池堆砂問題に関心を持ち, その基礎的問題を水理学的立場から総括的かつ系統的に 取りあげ, 堆砂率による貯水池寿命の推定 ${ }^{1), 22,3)}$, 貯水池 の堆砂分布 ${ }^{33}$, ,32),33),35), 堆砂機構に関する実験 ${ }^{3), 36), 40) ~ • ~}$ 解析 ${ }^{3,37), 39)}$, 水理学的特性 (主として密度流) と沈殿 堆積3,34),38)などの諸問題について若干の究明を行ない,

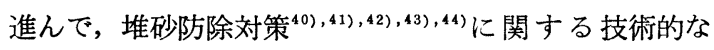
面の検討を続けている。これまでの経験的な堆砂率推 定 $^{1), 2), 3)}$ では, 国内外 337 個 (日本 272 個, アメリカ 93 個, フランス 8 個, 中華民国-台湾 3 個, トルコ 1 個) の ダム堆砂資料（わが国の資料は主として 1957 年度現在 のもの）を用いたが，その後日本 430 個（主として 1968 


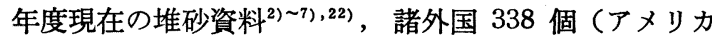
197 個, インド 73 個, 中華民国・台湾 12 個, フラン ス,イタリー, アラブ連合, アルジェリア, パキスタン

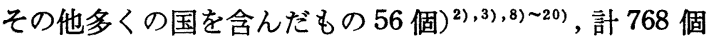
のダム堆砂資料が収集できたので, 再び堆砂の実態を巨 視的に解析し, 経験的に貯水ダムの設計堆砂量などを推 算する問題について検討した。

\section{2. わが国貯水池の堆砂現況と諸外国における 著例との比較}

人工貯水池の堆砂現象は, その供給源からみると, 流 域の規模や地形 - 地質, 地被状態, 水文気象条件, 渓 流・河川の水理学的特性, 人為的諸作用などに支配され る。他方, ダム築造面からみると, 貯水池の環境・立地 条件, 貯水池の規模, 貯水池形態, 貯水池の水理学的特 性（主として密度流）, 貯水位の変動, 流入土砂の特性, 沈殿阻止率, 築造後の経過年数, 全堆砂率, 貯水池操作 または排砂施設の有無・効率などきわて多くの因子に支 配され，堆砂の実態がそれぞれ関係する要素によって異 なっている。したがって貯水池の堆砂機構やその防除対 策を画一的に把握・樹立することは困難である。すなわ ち，堆砂を支配する情報因子がきわめて多いこと，その 実測定量化の手法で未開発部分が多く，実測による量的 表現が困難であること，また堆砂現象はその給源となる 流域からの土砂生産・流出が, 長期間の連続的形態をと る場合と, 不連続的で偶発的な形態をとる場合が混在し ていること，さらにまた主要な支配因子と考えられる水 文特性と土砂の生産・輸送・堆積の関係は非線型性が強 く, 情報理論的に取り扱ら方法を困難なものにしている こと,などのため, 適正な把握が困難である。

しかし, 堆砂の機構を究明し，その防災・減災対策を 確立するためには，堆砂給源となる流域内の土砂生産過 程と河道内の土砂輸送過程における機構, さらに貯水池 への流入土砂量や阻止率（捕促率）などを総合した土砂 の生産・輸送・堆積のシステム解析が必要となるが，ま ず貯水池の堆砂に関する実態を，長期間にわたったより 広範囲の既往実測資料を収集して適確に把握することが 急務である。この意味から堆砂支配因子の.うち, 比較的 容易に情報が得られる流域面積 $F$, 貯水容量 $C$, 平均年 流入水量 $I$, 平均年降水量 $P$, 洪水流量 $\boldsymbol{Q}$ (設計洪水流 量, 既往最大洪水流量または年最大洪水流量など), 経 過年数 $Y$ などを可能な限り収集して, 全堆砂率 $R_{s}$, 平 均年堆砂率 $r_{s}$ または平均比堆砂量 $q_{s}$ などと対応させ て巨視的な検討を行なった。

この際, 長期間の堆砂現象を総括してみると, 土壌侵 食やその他の土砂災害現象でみられるように，期間中の
偶発的なある特定の土砂生産・流出に左右されることが 多く, この点, 特定ダムの堆砂量を推算する場合にその 堆砂過程を確率過程とみなして, いわゆる時系列解析を 行なら方法 ${ }^{21)}$ も試みられてきた。しかし，ここでは国内 外のより多くのダムについて既往堆砂資料を収集し，普 遍性のある経験的な推定を目標としたため, 各情報因子 の単位を一応年間にとり平均操作によってきわめて巨視 的に処理した。

図一1 は, 全堆砂率 $R_{s}$ から貯水池の寿命を推定する ために, 日本 316 個（発電用ダム 300 個と $Y=160 \sim 450$ 年のかんがい用溜池 16 個含む), アメリカ 171 個, イ ンド 59 個, 中華民国 (台湾) 12 個, その他の国 33 個, 計 591 個のダム堆砂資料をもとにして, 経過年数 $Y$ （year）と全堆砂率 $R_{s}=100 S / C, \%$ ( $S$ : 全堆砂量, $\mathrm{m}^{3}$, $C$ : 原貯水量, $\mathrm{m}^{3}$ )の関係を, 埋没曲線をパラメーターに とって両対数紙に点描したものである。この際の $R_{s}$ は 各貯水池の観測年次における全堆砂量 $S$ のダム建設当 初の総貯水量に対する百分率を示すものであるから，図 -1のよ5に経過年数 $Y$ と対応させると, 埋没年数 $Y_{s}$ (year) の長短の比較ができ， $Y \leq 70$ を示す世界の主 要ダムでは, 特例を除いて $Y_{s}=10$ 年のはなはだ短いも のから， $Y_{s}=10000$ 年に至るはなはだ長いものまで, その変化のふれが著しい。この資料は観測最終年度の比 較であるが,個々の貯水池では, 全堆砂率の年変化曲線が 複雑な様相を示し，わが国の主要貯水池群では一応緩慢 型・中間型および急速型埋没貯水池に 3 分類できる ${ }^{2), 3) 。 ~}$ また図一1には, 表一1, 表一2にある $Y=160 \sim 450$ 年の 貯水池年令を示す小規模かんがい用溜池群（ボーリング による実測資料 $)^{22)}$ も併記してあるが，ほとんど $Y_{s}=$ $700 \sim 5000$ 年型の埋没曲線範囲であり，現に香川県内約

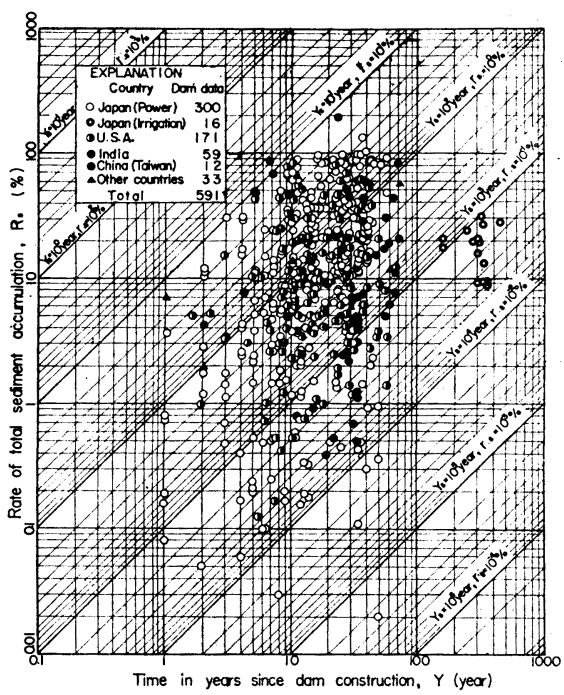

図一1 経過年数 $Y$ と全堆砂率 $R_{s}$ の関係 
表一1 収集ダム堆砂资料の䋓括

\begin{tabular}{|c|c|c|c|c|c|c|}
\hline \multirow[b]{2}{*}{ 国 } & \multirow[b]{2}{*}{ 別 } & \multirow{2}{*}{$\begin{array}{l}\text { 収集夕厶 } \\
\text { 資 料 }\end{array}$} & \multicolumn{2}{|c|}{ 平均年堆砂率 $r_{s}$} & \multicolumn{2}{|c|}{ 平均比堆砂量 $q_{s}$} \\
\hline & & & 供么試 & $\begin{array}{c}\text { 平均值 } \\
(\%)\end{array}$ & 供么試 & $\left.\begin{array}{c}\text { 平均值 } \\
\left(\mathrm{m}^{3} / \mathrm{km}^{2}\right. \\
/ \text { year }\end{array}\right)$ \\
\hline 日 & 本 ${ }^{*}$ & 414 & 366 & 1.71 & 277 & 533 \\
\hline 日 & 本** & 16 & 16 & 0.07 & - & - \\
\hline アメリ & & 197 & 189 & 1.16 & 185 & 580 \\
\hline $1=$ & & 73 & 59 & 0.57 & 59 & 537 \\
\hline 中華民国 & (台湾) & 12 & 12 & 4.51 & 12 & 6465 \\
\hline その他の & 国*** & 56 & 35 & 3.41 & 41 & 319 \\
\hline 計 & & 768 & 677 & & 524 & \\
\hline
\end{tabular}

備考 *: 主として発電用夕ム

**: 香川県内の $Y=160 \sim 450$ 年のかんがい用溜池, 表一2 参照

***: フランス, イタリー, アラフ連合, アルジリリアパキスタ ン，オーストラリア，その他多くの国去合んだ主要タム

表一2 かんがい用溜池の環境別堆砂状況 凟料の䋓括 (香川県) 22

\begin{tabular}{|c|c|c|c|c|c|}
\hline \multicolumn{2}{|c|}{ 貯 水 池 相 } & 実 測 数 & $\begin{array}{l}\text { 全堆砂率 } \\
R_{s}(\%)\end{array}$ & $\begin{array}{l}\text { 経過年数 } \\
Y \text { (年) }\end{array}$ & 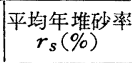 \\
\hline 山 & 池 & 3 & 22.9 & 260 & 0.092 \\
\hline 麓 & 池 & 5 & 20.7 & 304 & 0.074 \\
\hline 野 & 池 & 8 & 18.9 & 314 & 0.051 \\
\hline & 平均） & 16 & (18.5) & $(300)$ & $(0.066)$ \\
\hline
\end{tabular}

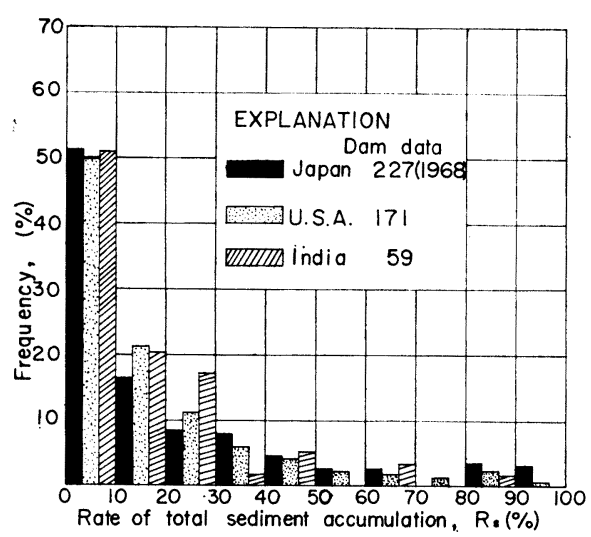

図一2 全堆砂率 $\boldsymbol{R}_{s}$ の頻度分布

18000 個のかんがい用溜池群の中には, 1200 有余年の 貯水池年令を示し，かさ上げ修築を重ねたとはいえ，い まなお $C=154 \times 10^{5} \mathrm{~m}^{3}$ の湛水をしている長寿型の満濃 池もある。

以上の全堆砂率資料のうち, 日本 227 個 (1968 年度 現在の主要発電用ダム堆砂資料), アメリカ 171 個およ びインド 59 個について全堆砂率 $R_{s}$ の頻度分布を示し たのが図一2である。これによると，わが国主要発電用 ダム群で, 経過年数が $Y=60 \sim 70$ 年以下のものを同一 レベルで論じることには多少の無理があるが，いま 1968 年度現在の実態を比較してみると， $R_{s}=50 \%$ 以上に達 して貯水容量の過半が埋没しているダムが約 $12 \%, R_{s}$ $=80 \%$ 以上に達して, 本来の機能を变失しているもの が約 $7 \%$ に達している現状である。これに対し, silt problems では世界の両雄と称するアメリカ，インドに
おける主要ダム群の例をみると，母集団のとり方が基準 年, 資料数などの点で異なっているが，その頻度分布が わが国のそれに類似していることは興味深い。

経過年数がそれぞれ異なる貯水池群の埋没危険性を, 全堆砂率 $R_{s}$ の值のみで比較するのは必ずしも適正でな い。この意味から, 式 (1) で求められる平均年堆砂率 $r_{s}$ で比較すると, 貯水池相互の堆砂による埋没速度が巨視 的に比較検討できる。

図一3 は, 日本 366 個, アメリカ 189 個, インド 59 個の主要ダムを対象にした $r_{s}$ 階級別頻度分布を示した もので, さらに表一 1 に示す $r_{s}$ の総括平均值などから みると, わが国主要ダムは, ほとんど河川の本流または 主要支川を山閒渓谷において締切った mountain reservoir に相当するものであるから，水文・気象環境などが さらに悪条件を示す中華民国（台湾）の例には及ばない としても, 埋没速度が一般に高いものといえよう。この

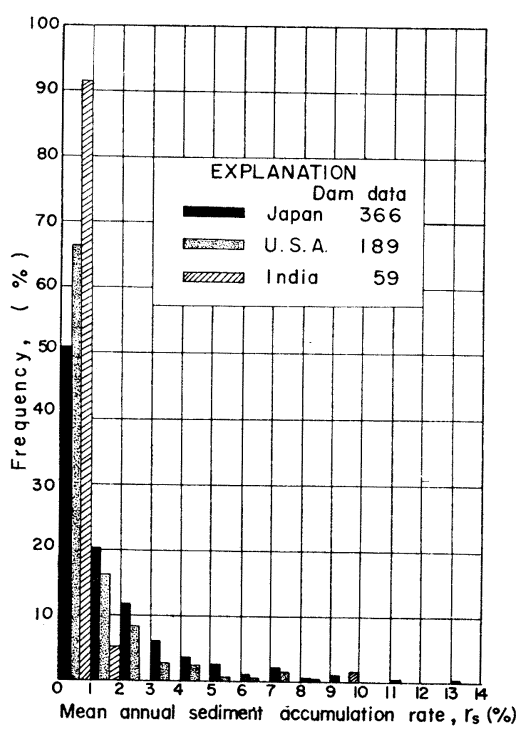

図一-3 平均年堆砂率 $\boldsymbol{r}_{s}$ の頻度分布

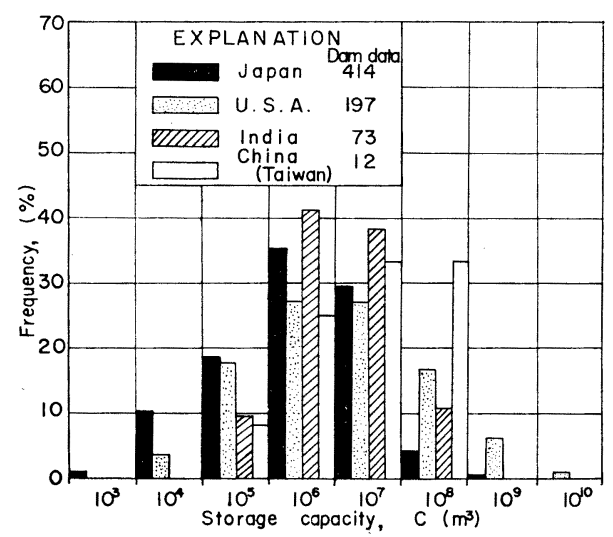

図-4 供試ダム原貯水容量の頻度分布 


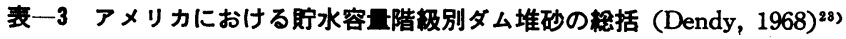

\begin{tabular}{c|c|c|c|c|c|c|c}
\hline $\begin{array}{c}\text { 貯水容量 } C \\
\text { (acre-ft) }\end{array}$ & 厶 数 & $\begin{array}{c}\text { 原貯水容量の䋓計 } \\
\Sigma C\left(\mathrm{~m}^{3}\right)\end{array}$ & $\begin{array}{c}\text { 全堆砂量の総計 } \\
\Sigma S\left(\mathrm{~m}^{3}\right)\end{array}$ & $\begin{array}{c}\text { 全堆砂率の平均 } \\
R_{s}(\%)\end{array}$ & $\begin{array}{c}\text { 平均経過年数 } \\
Y(\text { 年 })\end{array}$ & \multicolumn{2}{|c}{ 平均年堆砂率 $r_{s}$} \\
\hline $0 \sim 10^{1}$ & 161 & 844948 & 222030 & 26.3 & 11.0 & 3.41 & 2.20 \\
$10^{1} \sim 10^{2}$ & 228 & 10113467 & 2110519 & 20.9 & 14.7 & 3.17 & 1.32 \\
$10^{2} \sim 10^{3}$ & 251 & 119703774 & 20012304 & 16.7 & 23.6 & 1.02 & 0.61 \\
$10^{3} \sim 10^{4}$ & 155 & 602409329 & 63026916 & 10.5 & 20.5 & 0.78 & 0.50 \\
$10^{4} \sim 10^{5}$ & 99 & 5197142555 & 454897531 & 8.8 & 21.4 & 0.45 & 0.26 \\
$10^{5} \sim 10^{6}$ & 56 & 22535837772 & 782343675 & 3.5 & 16.9 & 0.26 & 0.13 \\
$10^{6}<$ & 18 & 47072279326 & 1650696837 & 3.5 & 17.1 & 0.16 & 0.10 \\
\hline 計 (平均) & 968 & 75538331171 & 2973309812 & 3.9 & 18.2 & 1.77 & 0.72 \\
\hline
\end{tabular}

祭, 供試ダム母集団の貯水容量階級別頻度分布は, 図一4 のよ5に供試ダム数の少ない台湾を除いて大体類似して おり， mode は $C=10^{6} \mathrm{~m}^{3}$ の order である。

$$
r_{s}=R_{s} / Y, R_{s}=100(S / C)
$$

ここに, $r_{s}:$ 平均年堆砂率 $(\%), R_{s}$ : 全堆砂率 $(\%)$, $Y:$ 経過年数 (年), $S:$ 全堆砂量 $\left(\mathrm{m}^{3}\right), C$ : 原貯水容量 $\left(\mathrm{m}^{3}\right)$ で，この際の $C$ は総貯水容量を採用しており， 現実に堆砂量の対象となるのは洪水吐越流頂部以下の容 量であるから, 式 (1) の $R_{s}, r_{s}$ から貯水池寿命を推定 するには過大評価の恐れはある。

また, 平均年堆砂率は貯水容量の規模によって異なる もので, Dendy ${ }^{23)}$ がアメリカ 968 個のダム資料をもと にまとめた表一3 によると, 貯水容量の増大に伴って平 均年堆砂率の平均值や中央值が減少する傾向が明瞭とな る。

他方, 堆砂の供給源から比較する場合には, 式 (2) か ら求められる平均比堆砂量 $q_{s}\left(\mathrm{~m}^{3} / \mathrm{km}^{2} /\right.$ year $)$, すなわち, 流域単位面積あたり 年堆砂量がよく用いられる。表一4 は平均比堆砂量の頻度分布を示すもので, 表一1に示し た総括平均值からみると, 中華民国 (台湾) の值は特例 として, 日本, アメリカおよびインドなどでは $q_{s}=500$ の order で近似している。

$$
q_{s}=S / F Y
$$

いま,わが国主要ダム堆砂量をもとにした平均比堆砂 量加ら, 国土総流出土砂量 $S_{T}$ を概算すると, $S_{T}=5 \times$

\begin{tabular}{|c|c|c|c|c|c|c|c|c|}
\hline \multirow{2}{*}{$\begin{array}{c}\boldsymbol{q}_{\boldsymbol{s}} \\
\left(\mathrm{m}^{3} / \mathbf{k m}^{2} / \text { year }\right)\end{array}$} & \multicolumn{2}{|c|}{ 日本 } & \multicolumn{2}{|c|}{ アメリカ } & \multicolumn{2}{|c|}{$1 ン F$} & \multicolumn{2}{|c|}{$\begin{array}{c}\text { 中華尾国 } \\
(\text { 台湾) }\end{array}$} \\
\hline & タムム数 & $\%$ & 夕人数 & $\%$ & |夕八厶数 & $\%$ & |夕ム数 & $\%$ \\
\hline $0 \sim \quad 200$ & 129 & 56.8 & 89 & 48.1 & 18 & 30.5 & 1 & 8. \\
\hline $200 \sim 400$ & & 11.9 & 39 & 21.1 & 11 & 18. & 0 & 0 \\
\hline $400 \sim 600$ & & 8. & 11 & 5 & 8 & 13. & 1 & 8. \\
\hline $600 \sim 800$ & 1 & 4.8 & 14 & 7.6 & 9 & 15.3 & 0 & 0 \\
\hline $800 \sim 1000$ & & 4.0 & 14 & 7.6 & 3 & 5.1 & 0 & 0 \\
\hline $1000 \sim 2500$ & 18 & 7.9 & 13 & 7.0 & 10 & 16.9 & 4 & 33.4 \\
\hline $2500 \sim 5000$ & 10 & 4.4 & 3 & 1.6 & 0 & $\because 0$ & 0 & 0 \\
\hline $5000 \sim 7500$ & 2 & 0.9 & 0 & 0 & 0 & 0 & 1 & 8.3 \\
\hline $7500 \sim 100$ & & 0.5 & 0 & 0 & 0 & 0 & 2 & 16.7 \\
\hline $10000 \sim 25000$ & 0 & 0 & 2 & 1.1 & 0 & 0 & 3 & 25.0 \\
\hline 計 & 227 & 100 & 185 & 100 & 59 & 100 & 12 & 100 \\
\hline
\end{tabular}

表一4 平均比堆砂量 $\boldsymbol{q}_{8}$ の頻度分布 $10^{2}\left(\mathrm{~m}^{3} / \mathrm{km}^{2}\right) \times 369 \times 10^{3}\left(\mathrm{~km}^{2}\right)=1845 \times 10^{5}\left(\mathrm{~m}^{3}\right)$, すなわ ち, 年間に約 1.8 億 $\mathrm{m}^{3}$ の土砂流出が見込まれることに なる。しかし, この值は, 比較的土砂流出が大きい貯水 池の堆砂量から算出された数值であり,また国土の約 $1 / 3$ の流出土砂量の少ない平坦部も含まれているわけである から, 過大評価となり, 矢野 ${ }^{46)}$ が $q_{s}=400 \mathrm{~m}^{3} / \mathrm{km}^{2} /$ year として概算した $S_{T}=1.5$ 億 $\mathrm{m}^{3}$ 程度が妥当な数值と考 えられる。他方, 農林省林野庁調査 ${ }^{45)}$ では, 国土の約 $2 / 3$ の山地からは $S_{T} \doteqdot 1010 \times 10^{5} \mathrm{~m}^{3}$ (有害土砂量 $740 \times 10^{5}$ $\mathrm{m}^{3}$, 無害有効土砂量 $270 \times 10^{5} \mathrm{~m}^{3}$ ) の土砂流出を推定し ている。いま国土からの総流出土砂量は約 1.0 1.5 億 $\mathrm{m}^{3}$ とし, 無害有効土砂量を約 $20 \%$ 見込むと, 制御対 象となる有害土砂量は $S_{T} \doteqdot 0.8 \sim 1.2$ 億と推算される。 この際, 無害有効土砂量 $S_{T} \doteqdot 0.2 \sim 0.3$ 億 $\mathrm{m}^{3}$ は, それ ぞれ河道の安定, 海岸侵食の誘起防止または建設のため の河川砂利給源として効用をもたらすことになる。

また, 河川上流部のダム堆砂の未利用骨材資源の開発 も, 有害土砂としてのダム堆砂障害の防除と未開発資源 活用の両面から一石二鳥の効果が期待されているが，こ の点, わが国発電用ダムのうち, 総貯水量 $C=100$ 万 $\mathrm{m}^{3}$ 以上でダム高 $15 \mathrm{~m}$ 以上の 240 地点の結果 (1968 年度 現在 ${ }^{4)}$ では, 貯水容量合計 $C_{T}=734538 \times 10^{4} \mathrm{~m}^{3}$ に対 して, 堆砂量合計は $S_{T}=45786 \times 10^{4} \mathrm{~m}^{3}$ で約 $6 \%$ に達 している。いま砂利採取可能率を約 $50 \%$ と見込むと, $S_{T}=22893 \times 10^{4} \mathrm{~m}^{3}$ が採取可能堆砂量となり, 他方全 国砂防ダム 19991 個の堆砂採取可能量は $S_{T}=1999 \times$ $10^{4} \mathrm{~m}^{3}$ と見込まれており, その他の主要ダム堆砂を合 計すると，全国的には $S_{T} \doteqdot 5$ 億 $\mathrm{m}^{3}$ 以上の未利用砂利 資源が考えられる。

ダム堆砂は, 環境立地条件によっても左右されるもの で, 地域, 水系または同一水系内でも立地によって異な ってくる。表一5 はわが国の堆砂資料を地域別にまとめ たもので, 東海・北陸を含む中部地方が最も著しく, 他方 堆砂給源からみれば台風災害の頻発する四国地方が流域 単位面積あたりの流出土砂量が最も多いことがうかがえ る。また水系・河川によっても堆砂現象が異なるもので， 表一6 はわが国の同一水系内に堆砂凟料 3 個以上得られ 
表一5 わが国における地域別主要ダム群の堆砂

\begin{tabular}{|c|c|c|c|c|}
\hline \multirow{2}{*}{ 地 域 別 } & \multicolumn{2}{|c|}{ 平均年堆砂率 $r_{s}$} & \multicolumn{2}{|c|}{ 平均比堆砂量 $q_{s}$} \\
\hline & 供試夕ム数 & 平均值 $(\%)$ & 供試夕ム数 & $\mid \begin{array}{c}\text { 平 均 值 } \\
\left(\mathrm{m}^{3} / \mathrm{km}^{2} / \text { year }\right)\end{array}$ \\
\hline 北海道地方 & 21 & 2.17 & 11 & 297 \\
\hline 東北地方 & 50 & 1.28 & 28 & 237 \\
\hline 関東地方 & 31 & 1.51 & 16 & 492 \\
\hline 中部地方 & 115 & 2.38 & 83 & 594 \\
\hline 近戴地方 & 30 & 1.46 & 15 & 469 \\
\hline 中国地方 & 37 & 1.34 & 24 & 388 \\
\hline 四国地方 & 31 & 1.82 & 17 & 1220 \\
\hline 九州地方 & 51 & 1.15 & 33 & 523 \\
\hline
\end{tabular}

表一6 わが国における水系別主要ダム群の堆砂

\begin{tabular}{|c|c|c|c|c|c|c|c|}
\hline \multirow{2}{*}{$\begin{array}{l}\text { 地域別 } \\
\text { 配 列 }\end{array}$} & \multirow[b]{2}{*}{ 水 系 } & \multicolumn{2}{|c|}{ 平均年堆砂率 $r_{s}$} & \multirow{2}{*}{ 地域別 } & \multirow[b]{2}{*}{ 水 系 } & \multicolumn{2}{|c|}{ 平均比堆砂量 $q_{s}$} \\
\hline & & 供 試 & $\begin{array}{c}\text { 平均値 } \\
(\%)\end{array}$ & & & $\begin{array}{l}\text { 供 試 } \\
\text { 夕数 }\end{array}$ & $\left.\begin{array}{l}\text { 平 均 值 } \\
\left(\mathrm{m}^{3} / \mathrm{km}^{2}\right. \\
/ \text { year }\end{array}\right)$ \\
\hline 東北 & 北上川 & 3 & 1.94 & 北海道 & 石 狩 川 & 7 & 266 \\
\hline$"$ & 最上川 & 9 & 1.79 & 東北 & 最上川 & 8 & 452 \\
\hline 関東 & 利 根 川 & 16 & 1.22 & $"$ & 北上川 & 4 & 266 \\
\hline 中部 & 神通川 & 8 & 4.16 & $"$ & 阿賀野川 & 15 & 252 \\
\hline$"$ & 黒 部 川 & 3 & 3.57 & 関東 & 利 根 川 & 12 & 590 \\
\hline$"$ & 天 竜 川 & 6 & 2.64 & $"$ & 相 模 川 & 3 & 112 \\
\hline$"$ & 大井川 & 11 & 2.61 & 中部 & 黒 部 川 & 3 & 2973 \\
\hline$"$ & 富士川 & 6 & 2.25 & 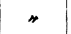 & 大井川 & 9 & 1530 \\
\hline " & 戌川 & 10 & 2.24 & $"$ & 常願寺川 & 3 & 499 \\
\hline " & 常願寺川 & 5 & 2.07 & $"$ & 生川 & 8 & 415 \\
\hline$"$ & 木 曽川 & 21 & 1.94 & " & 天竜川 & 5 & 410 \\
\hline$"$ & 信 濃 川 & 17 & 1.88 & " & 木曽川 & 19 & 364 \\
\hline 中国 & 太田川 & 4 & 1.11 & " & 信 濃 川 & 13 & 279 \\
\hline 四国 & 删 賀 川 & 3 & 2.48 & " & 富士川 & 3 & 112 \\
\hline$"$ & 物 部 川 & 3 & 1.42 & 近畿 & 熊野川 & 4 & 597 \\
\hline$"$ & 奈判利川 & 3 & 1.41 & 四国 & 吉 野 川 & 6 & 865 \\
\hline$"$ & 淀川 & 3 & 1.38 & 九州 & 小丸川 & 5 & 1321 \\
\hline 九州 & 大淀川 & 7 & 2.16 & $"$ & 耳 川 & 5 & 794 \\
\hline " & 小丸川 & 5 & 1.20 & $"$ & 大腚川 & 6 & 322 \\
\hline$"$ & 一ツ瀨川 & 3 & 1.19 & " & 大分川 & 3 & 247 \\
\hline
\end{tabular}

た主要 20 水系について, 水系別に平均年堆砂率および 平均比堆砂量を概略的にまとめたもので, 荒廃河川の多 い中部地方が最も埋没危険性が高いことがうかがえる。

さらに同一水系内に分布する棚池的ダム群でも, 上流 側ダムが最も埋没危険性が高く, 中・下流側のダムが堆 砂速度が緩慢となりその堆砂機構も異なってくるはずで あり，現にダム築造による河川開発が進んでいる，庄 川, 神通川, 黒部川, 常願寺川, 木曾川などの水系で は，一般に上流側のダムほど $r_{s}$ が大きくなる傾向を示 している。この点前川 ${ }^{24)}$ は香川県内に古くから分布して いるかんがい用溜池群 711 個の調査により，その環境別 標高は, field reservoir が $20 \mathrm{~m}$ 前後に, mountain reservoir は $100 \mathrm{~m}$ 付近に多く,また hill-side reservoir は 20〜80 m の中位に立地するものが多い傾向を 認めており，表一2 のように，一般に高標高に立地する 山池, 麓池の方が低標高に立地する野池に比較して平均 年堆砂率が高い傾向を示している。以上の資料のうちに は, 調整池ダムのようにすでに洪水吐越流頂部まで満砂 しているもの，また本流筋と流砂条件が異なる支流を含
表一7 わが国主要ダムの堆砂状況（貯水容量 $C=10^{7} \mathrm{~m}^{8}$ 以上, 平均比堆砂量 $q_{s}=10^{3} \mathrm{~m}^{3} / \mathrm{km}^{2} /$ year 以上の 主要ダム)

\begin{tabular}{|c|c|c|c|c|c|c|}
\hline $\begin{array}{l}\text { 順位 } \\
\left(q_{s}\right)\end{array}$ & タム & 名 & 水 系 & $\begin{array}{c}q_{s} \\
\left(\begin{array}{c}\mathrm{m}^{3} / \mathrm{km}^{2} \\
/ \mathrm{year}^{2}\end{array}\right)\end{array}$ & $\begin{array}{c}r_{s} \\
(\%) \\
\end{array}$ & $\begin{array}{c}C / F \\
\left(\mathrm{~m}^{3} / \mathrm{m}^{2}\right)\end{array}$ \\
\hline 1 & 黒部川第 & & 黒 部 川 & 8600 & 0.89 & 1.0733 \\
\hline 2 & 畑 薙 第 & & 大井川 & 6089 & 1.80 & 0.3377 \\
\hline 3 & 渡 & 川 & 小丸川 & 4432 & 1.13 & 0.4185 \\
\hline 4 & 井 & 川 & 大井川 & 3954 & 1.21 & 0.3290 \\
\hline 5 & 上 & 莱 & 耳 川 & 3621 & 1.15 & 0.3144 \\
\hline 6 & $\equiv$ & 浦 & 木曾川 & 3114 & 0.35 & 0.8965 \\
\hline 7 & 只 & 見 & 阿賀野川 & 2936 & 0.24 & 1.2492 \\
\hline 8 & 永 & 瀬 & 物 部 川 & 2853 & 0.95 & 0.1992 \\
\hline 9 & 長 & 沢 & 吉野川 & 2550 & 0.56 & 0.4556 \\
\hline 10 & 立 & 花 & 一ツ瀬川 & 2010 & 1.06 & 0.2433 \\
\hline 11 & 二 & 又 & 犀 川 & 1886 & 0.80 & 0.2353 \\
\hline 12 & 黒又川第 & & 信 濃川 & 1741 & 0.54 & 0.3231 \\
\hline 13 & 河 & 本 & 高梁川 & 1722 & 2.24 & 0.0769 \\
\hline 14 & 松＼cjkstart尾 & 川 & 吉野川 & 1660 & 0.46 & 0.3648 \\
\hline 15 & 生 & 川 & 九頭竜川 & 1447 & 0.18 & 0.8322 \\
\hline 16 & 笠 & 掤 & 信 濃 川 & 1329 & 0.65 & 0.2043 \\
\hline 17 & 八久 & 和 & 最上川 & 1197 & 0.38 & 0.3152 \\
\hline 18 & 丸 & 沼 & 利 根 川 & 1132 & 0.16 & 0.6904 \\
\hline 19 & 猿 & 田 & 三面川 & 1093 & 0.83 & 0.1325 \\
\hline 20 & 佐 久 & 間 & 天 竜 川 & 1031 & 1.21 & 0.0854 \\
\hline 21 & 朝 & 日 & 木曾川 & 1009 & 0.89 & 0.1134 \\
\hline
\end{tabular}

めた水系全体のダム資料を加味している関係で適正な水 系別代表值とはいえないが，一応同一の地域，水系また は環境内にダムを築造する場合の堆砂量評価の目安とな 万う。

表一7 は, 比堆砂量が $q_{s}=10^{3}\left(\mathrm{~m}^{3} / \mathrm{km}^{2} /\right.$ year $)$ 以上の ダムのうち貯水容量 $C=10^{7}\left(\mathrm{~m}^{3}\right)$ 以上のわが国主要ダム の堆砂指標 $\left(q_{s}, r_{s}, C / F\right)$ を示したものである。これに よると，中華民国(台湾) での例， $q_{s}=10^{4}\left(\mathrm{~m}^{3} / \mathrm{km}^{2} /\right.$ year), 以上 ${ }^{9)}$ の記録にはおよばないとしても，黒部川第 4 ダム などでは土石流の頻発で設計比堆砂量を超過した堆砂実: 態を示しており，巨額の経費を投じて築造された貯水池 が，土砂堆積によってみすみすその機能を低下・言失す る問題が重要視されてきた。たとえば，黒部川第 4 ダム 設計当初の設計堆砂量は 100 年堆砂で $S_{100}=13540000$ $\left(\mathrm{m}^{3}\right)$, 設計比堆砂量 $q_{s}=734\left(\mathrm{~m}^{3} / \mathrm{km}^{2} /\right.$ year $)$ とされてい るのに対し ${ }^{25)}, 1968$ 年度現在（経過年数 $Y=7$ 年）の. 実測全堆砂量は $S_{7}=11117628\left(\mathrm{~m}^{3}\right)$ で, 設計堆砂量の, 約 82 年堆砂に達している計算になり, 平均倍堆砂量も, 表一7のように設計比堆砂量の 約 10 倍以上 $\left(q_{s}=8600\right.$ $\mathrm{m}^{3} / \mathrm{km}^{2} /$ year) に評価される。

さらに, その後 1969 年度 ${ }^{26)}$ の年間堆砂量をみると $S$, $=6521995 \mathrm{~m}^{3}\left(r_{s}=3.27 \%, q_{s}=35254 \mathrm{~m}^{3} / \mathrm{km}^{2} /\right.$ year $)$ の ごとく異常な值を示しており，しかもその大部分が 8 月 豪雨出水に基づくものであることからみて，このような 個々のダム堆砂災害の適正評価には, さらに時系列的取 り扱いの必要性が痛感される。たとえば, 特定の水系・ 流域における貯水池の堆砂を考慮する場合なら, 堆砂支 配因子のうち地形・地質・地被条件などの変化は一般に 
緩慢であり，設計堆砂 100 年程度の期間内における土砂 の流出・堆積の系列を支配する主要因子は水文時系列特 性であると考えられる。この点, 確率事象としての土砂 収支に対する支配水文量の評価決定については若干の指 摘 $^{21)}{ }^{26)}$,32),47) がなされてきたが解決の域に達していな 心。

\section{3. 貯水池の $\boldsymbol{C} / \boldsymbol{F}$ 比と平均年堆砂率ならびに平 均比堆砂量の関係}

土砂給源の広狭を表わす流域面積は，その流域に加え

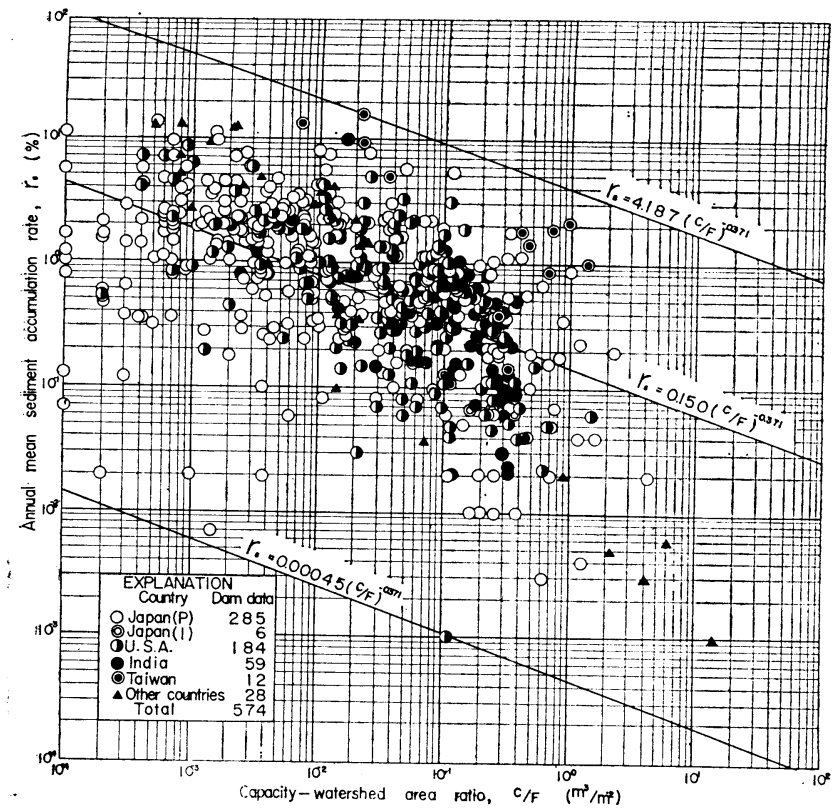

図一-5 $\boldsymbol{C} / \boldsymbol{F}$ 比と平均年堆砂率 $\boldsymbol{r}_{s}$ の関係

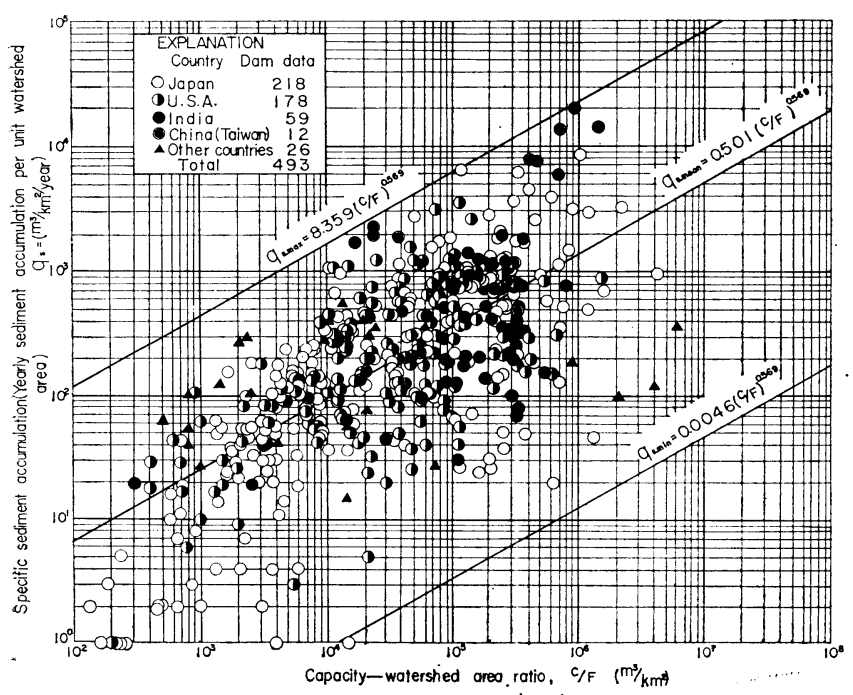

図-6 C/F 比と比堆砂量 $\boldsymbol{q}_{s}$ の関係
られる外力としての降雨量, 流出水量などの大小を表わ す重要な因子であり，したがって流出土砂量ひいては貯 水池の堆砂量に密接な関係を有してくる。他方貯水池自 体からみれば, 堆砂能を表わす貯水容量の大小が直接埋 没年数の長短に密接な関係があり，堆砂率や trap efficiency などを左右する重要な パラメーターとなってく る。このような観点から, 日本 291 個, アメリカ 184 個，インド 59 個，中華民国 (台湾) 12 個，その他の国 28 個, 計 $N=574$ 個のダム堆砂資料をもとにして, 情 報の収集が容易な貯水容量 $C$ と流域面積 $F$ との比, $C / F$ を採用し, 平均年堆砂率 $r_{s}$ との関係について再検 討した。その結果を示したのが図一5 であり， $\log r_{s}$ と $\log C / F$ の相関係数は $r=-0.540 * * *$ (以下, * : 有意水準 $P<0.05, * *: P<0.01$, *** : $P<0.001$ でそれぞれ有意,非常に有意な 相関を示す）で非常に有意な逆相関が認められ る。したがって最小自乗法により経験式を求め ると式 (3) が得られ， $K$ 值は $\max (4.187)$, mean (0.150), $\min (0.00045)$ となる。ここに 単位は $r_{s}(\%), C\left(\mathrm{~m}^{3}\right), F\left(\mathrm{~m}^{2}\right)$ である。

$$
r_{s}=K(C / F)^{-0.371}
$$

また, 日本 218 個, アメリカ 178 個, インド 59 個，中華民国（台湾） 12 個，その他の国 26 個, 計 $N=493$ 個のダム堆砂資料をもとにし て, $C / F$ ratio と平均比堆砂量 $q_{s}$ との関係を 示したのが, 図一6 であり, $\log q_{s}$ と $\log C / F$ の相関係数は $r=0.686 * * *$ で非常に有意な順 相関が認められる。また経験式としては式 (4) が得られ, $K$ 值は $\max (8.359)$, mean(0.501), $\min (0.0046)$ となり, この場合の単位として は, $q_{s}\left(\mathrm{~m}^{3} / \mathrm{km}^{2} /\right.$ year $), C\left(\mathrm{~m}^{3}\right), F\left(\mathrm{~km}^{2}\right)$ をそれ ぞれ用いた。

$$
q_{s}=K(C / F)^{0.569}
$$

このような $C / F$ ratioを単一または複合的に 貯水池の堆砂量, 堆砂率または沈殿阻止率 $E_{T}$ などと関連づけた経験式の算出は表一8 (式 5〜 16）のように, Witzig ${ }^{27)}$, 鶴見 ${ }^{28)}$, 著者 ${ }^{12,2), 3)}$, Jenkins ${ }^{13)}$, Flaxman ${ }^{29)}$, Gottschalk ${ }^{30)}$, Woodburn $^{31)}$, Brown $^{18)}$, Brune $^{19)}$ などにより試みられ ているが,広範囲の資料を用いた解析とはいえ， 特定の国または地域に限られたものである。こ の点本解析では, より広範囲の国・地域にわた った主要ダム資料（493〜574 個）を用いたもの であり，有意な相関が認められることからして も，国際的な広範の地域全体としてのダム堆砂 の傾向を総括的につかみ得る点で一般性がある ものといえよう。しかし，要因解析にあたって 
表一8 C/F 比, $C / I$ 比を単一または複合的に用いた経験式

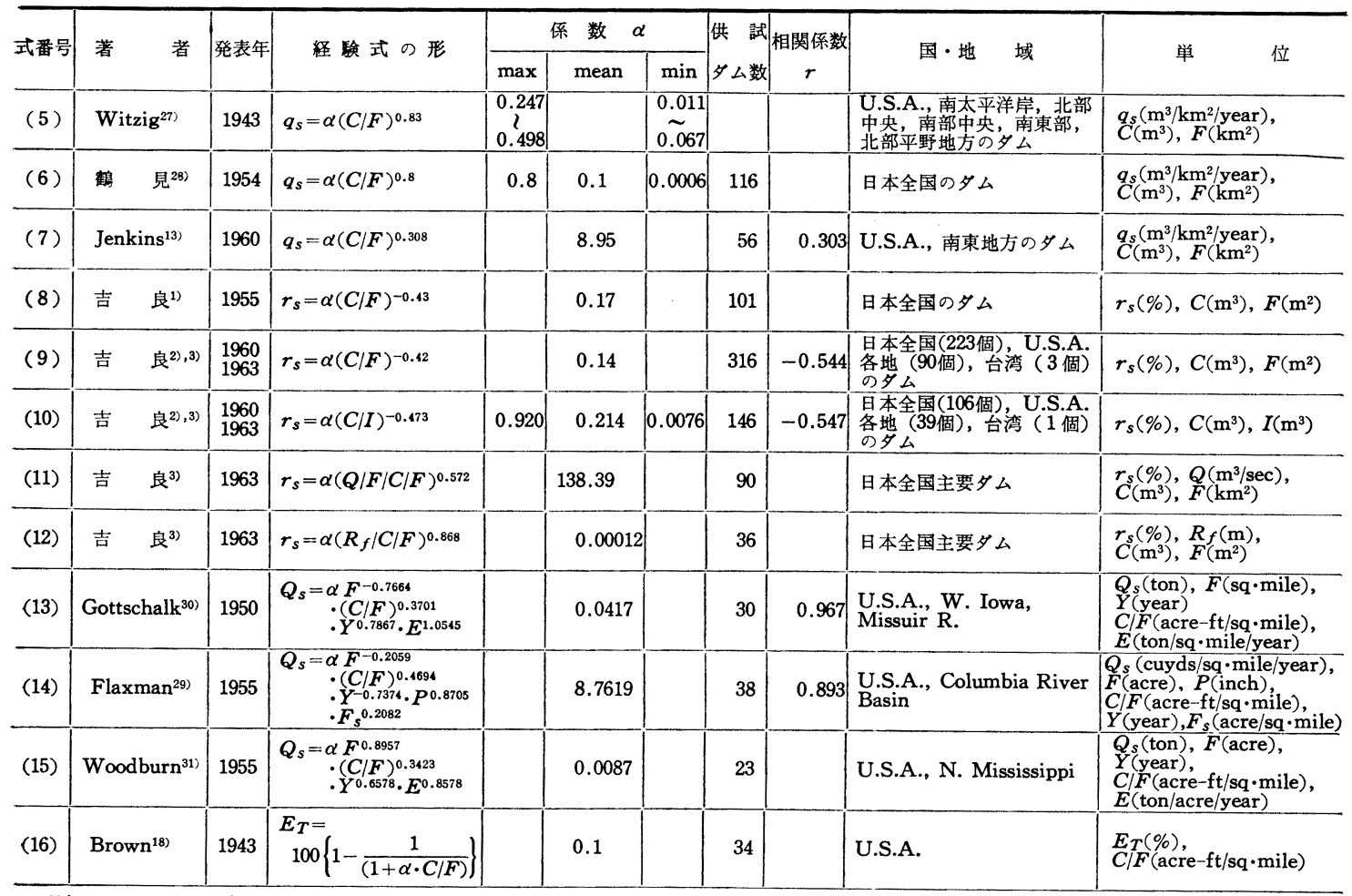

注） $q_{s}$ : 比堆砂量, $C:$ 原貯水容量, $F:$ 流域面積, $r_{s}:$ 平均年堆砂泍, $I:$ 平均年流入水量, $Q$ : 設計洪水流量, $R_{f}:$ 起伏量, $Y:$ 経過年数, $E:$ 侵食率, $P:$ 年雨量, $F_{S}:$ 侵食面積, $E_{T}:$ 沈殿阻止率

収集しやすい 2 変数処理を行なったため資料の描点がば らついており， $K$ 值も平均值の外に 総括上限および下 限値のみで, これを流域個々のダム堆砂量の推定には利 用し難い面があることは否定できない。すなわち，元来 ダム堆砂量は流域の地形・地質・地被条件や水文・気象 条件などの要因により地域性がきわめて高いものである から, 式 (3),(4) において regional index を意味する 地域別 $K$ 值の評価がぜひ必要となる。この点,一般に は同一環境内資料の集積不足の点で至難であり，一応年 降水量などについて検討したが, 妥当な結果が得られな かった。

\section{4. 貯水池の $\boldsymbol{C} / \boldsymbol{I}$ 比と平均年堆砂率ならびに 平均比堆砂量の関係}

前項では, 貯水能を表現する指標として $C / F$ ratio を 用いたが, 流域面積より直接土砂の流送に関係深い平均 年流入水量 $I$ に対する貯水容量の比, $C / I$ ratio を採用 して, 平均年堆砂率 $r_{s}$ および平均比堆砂量 $q_{s}$ と対応 させた。

図一7 は, 日本 156 個, アメリカ 59 個,インド 47 個，その他の国 11 個，計 $N=273$ 個のダム堆砂資料を
もとにして，C/I ratio と平均年堆砂率 $r_{s}$ の関係を示 したもので, $\log r_{s}$ と $\log C / I$ の相関係数は $r=$ $-0.600^{* * *}$ で非常に有意な逆相関が認められる。したが って，この際の経験式は式 (17) となり， $K$ 值は $\max$ (1.850), mean $(0.160), \min (0.0057)$ が得られる。な おこの場合の単位は $r_{s}(\%), C\left(\mathrm{~m}^{3}\right), I\left(\mathrm{~m}^{3}\right)$ である。

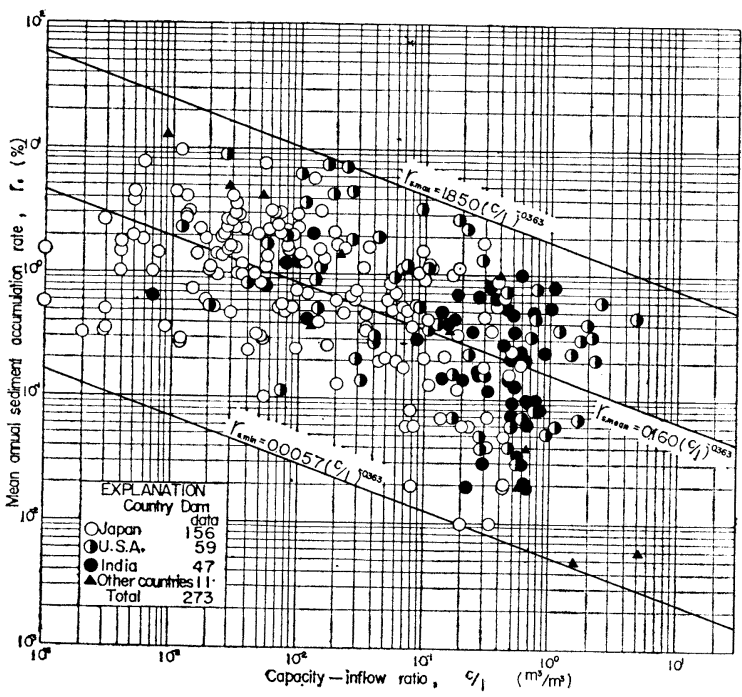

図一7 C/I 比と平均年堆砂率 $\boldsymbol{r}_{s}$ の関係 


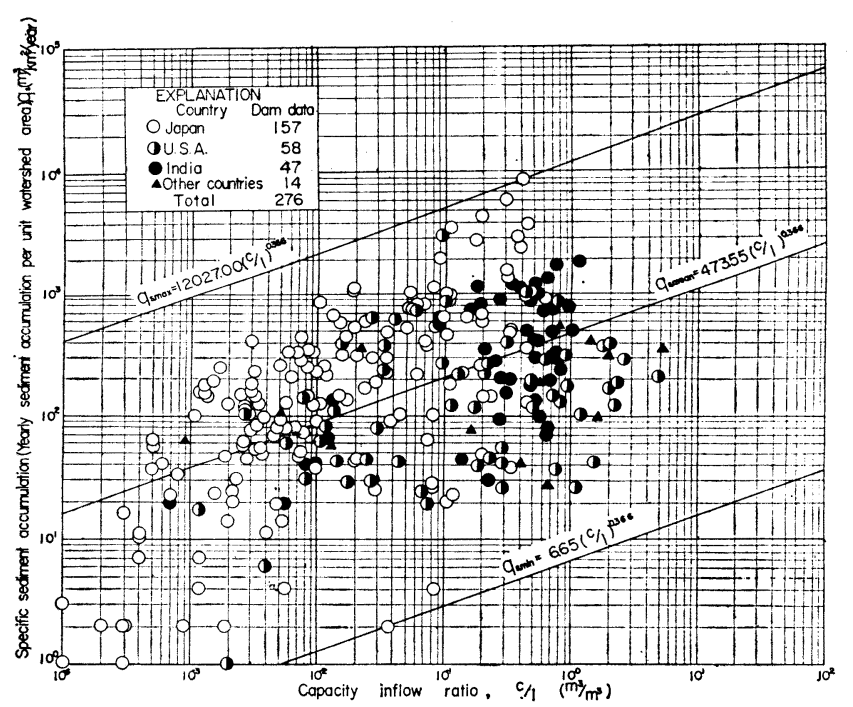

図一8 $C / I$ 比と比堆砂量 $\boldsymbol{q}_{s}$ の関係

同様に, 図一8 は日本. 157 個,アメリカ 58 個, インド 47 個, その他の国 14 個, 計 $N=276$ 個のダム堆砂資料を 用いて $C / I$ ratio と平均比堆砂量 $q_{s}$ の関係を点描したも ので,この際の $\log q_{s}$ と $\log C / I$ の相関係数は $r=0.545$ *** で非常に有意な順相関が認められる。したがって経 験式として式 (18) が得られ， $K$ 值は $\max (12027.00)$, mean (437.55), $\min (6.65)$ となる。な弾位としては $q_{s}\left(\mathrm{~m}^{3} / \mathrm{km}^{2} /\right.$ year $), C\left(\mathrm{~m}^{3}\right), I\left(\mathrm{~m}^{3}\right)$ をそれぞれ用いた。

$$
q_{s}=K(C / I)^{0.366}
$$

$C / I$ ratio を単一に貯水池の堆砂率や阻止率な ぞと関連づける試みは， Brown $^{18)}$, Brune $^{199}$ ，著 者 $^{2)}$ (3)などによりなされてきたが, この解析では， より広範囲の国・地域にわたった主要ダム堆砂資 料（273 276 個）を用いた点, さらに $C / I$ ratio は長期間にわたる retention time の平均を表わ すこと, $C / F$ ratio の場合と異なり無次元表示で あること，または $r_{s}$ との対応の場合には $C / F$ ratio を用いた場合より相関が高いことなどの点 から，国際的な広範囲の地域全体としてのダム堆 砂の傾向を総括的につかみ得る点で，相当信頼度 も高く応用性があるものと考えられる。

すなわち, 平均年堆砂率 $r_{s}$ のような平均的状 態を指向する場合には, 流域の状態や降雨・出水 量がさほど変動しない限り, 同一貯水池では大体 一定とみなされるから，C/I ratio が重要な支配 要因となってくる。しかし, 前述 $C / F$ ratio の 場合と同様に, 要因解析にあたって 2 変数処理を 行なった結果, その描点も多少ばらついており, さらに regional index としての地域別 $K$ 值の

評価をしなければ，これを流域個々のダム堆砂 量の推定に利用しがたい面があることは否定で きない。また $C / F$ ratio の方は貯水池計画に 際して容易に得られる要因であるが, $C / I$ ratio の方は，ダムサイト地点における長期間にわ たった年間流入水量の観測資料が必要となり， 資料収集の点で難点がある。この点に関し，日 本 180 個，アメリカ 60 個，インド 52 個，その 他の国 20 個, 計 312 個のダム資料について, $C / F$ ratio と $C / I$ ratio の関係を両対数紙に点 描してみると図一9 のごとく，日本 $(C / F$ と $C / I$ の相関係数は $\left.r=0.851^{* * *}\right)$, インド $(r=$ $\left.0.613^{* * *}\right)$ などでは，ほぼ linear な有意な相 関を示しており, 傾向として日本のダム群が最 も retention time が短く, $C / I=\alpha(C / F)^{\beta}$ の 関係で示すと $\alpha$ 值が最も小さく, したがって堆 砂支配因子としての流域内からの降雨の流出が きわめて多いことがうかがえる。この際の単位としては $C\left(\mathrm{~m}^{3}\right), F\left(\mathrm{~m}^{2}\right), I\left(\mathrm{~m}^{3}\right)$ を用いた。

\section{5. 貯水池の比流量 $\boldsymbol{Q} / \boldsymbol{F}$ と平均比堆砂量の関係}

個々の貯水池堆砂量は, 主として期間内の異常な水文 ・気象条件や流域内の人為的作用などに支配される場合 が多い。たとえば長安口ダム ${ }^{32)}$ の年最大洪水流量 $Q_{\max }$ $\left(\mathrm{m}^{3} / \mathrm{sec}\right)$ と年間比堆砂量 $q_{s}\left(\mathrm{~m}^{3} / \mathrm{km}^{2} /\right.$ year $)$ の関係をみ ると式 (19) に示すように linear な順相関が認められ,

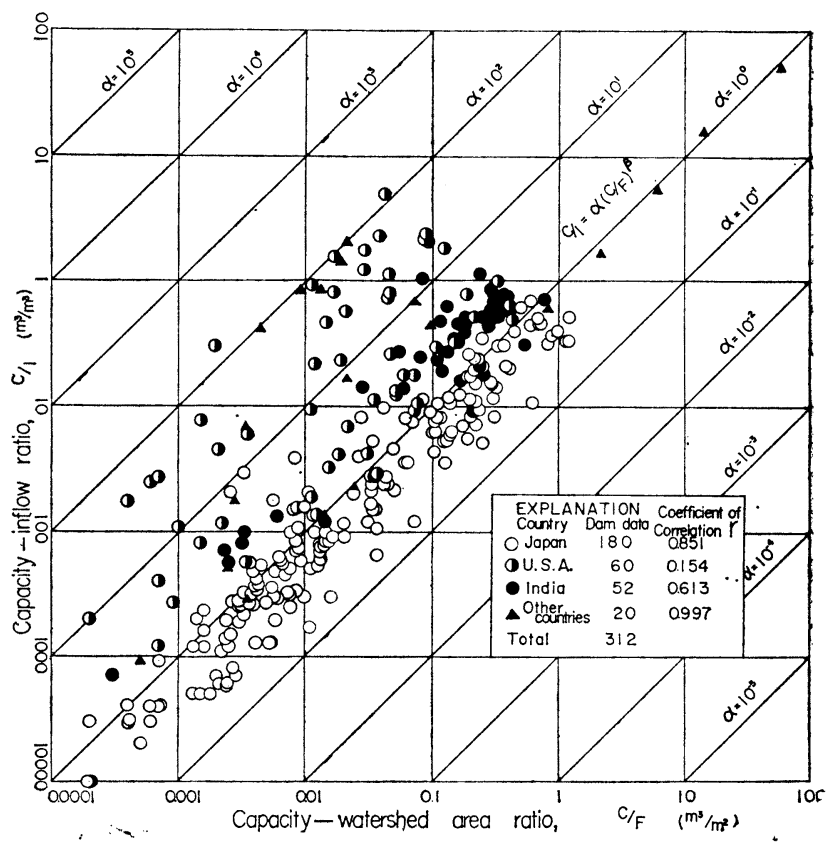

图一9 $\boldsymbol{C} / \boldsymbol{F}$ 比と $\boldsymbol{C} / \boldsymbol{I}$ 比の関係 
その他千頭・王泊・久瀬などのダムの例 ${ }^{47}$ では比堆砂量 $q_{s}$ の年変化と 年最大洪水比流量の 年変化との間には密 接な関係が認められており，同様なことは黒部川第 4 ダ 厶 $^{26)}$ でもいえ, 年最大日流量と年間流入土砂量の関係で は流量の 2 乗に比例するような関係が得られている。

$$
q_{s}=2.2 \times 10^{-7} Q_{\max }{ }^{2.8}
$$

このような観点から，個々の貯水池ではなく，わが国 $N=137$ 個の主要貯水池について, 設計洪水流量の比流 量 $Q / F\left(\boldsymbol{Q}\right.$ : 設計洪水流量, $\mathrm{m}^{3} / \mathrm{sec}, F$ : 流域面積, $\mathrm{km}^{2}$ を採用）と平均比堆砂量 $q_{s}\left(\mathrm{~m}^{3} / \mathrm{km}^{2} /\right.$ year $)$ の関係を総 括してみると, 図一10 に示すように $\log q_{s}$ と $\log Q / F$ の相関係数は $r=0.533 * * *$ で非常に有意な順相関が認 められる。したがって総括的な経験式として式 (20) が 得られ, $K$ 值の範囲として $\max (308.4)$, mean(14.2), $\min (0.5)$ が与えられる。

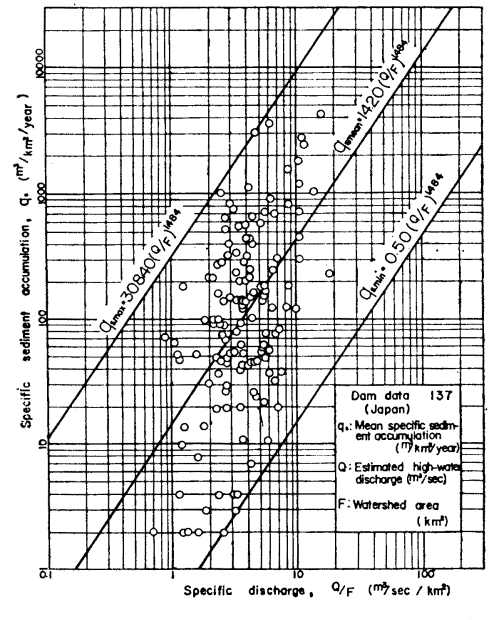

図-10 比流量 $Q / F$ と比堆砂量 $\boldsymbol{q}_{s}$ の関係

$q_{s}=K(Q / F)^{1}$

この場合も, regional index としての地域別 $K$ 值の 評価が必要となるが， $C / F$ や $C / I$ と対応させた場合の 図一6, 図一8, 式 (4), 式 (18) などと比較すると, わが 国のみの資料とはいえ $q_{s}$ の回帰指数曲線 $(K=$ mean の 場合）からの分散・標準偏差などが小さく，総括的にみ ても，このような土砂輸送過程における流量との対応が よくなる傾向を示している。

以上の解析結果は広範囲の国または地域にわたった主 要貯水池の堆砂について巨視的な傾向を示したものであ り, 個々のダムについて, 設計堆砂量などを適確に推算 する場合には，たとえば各経験式の $K$ 值を地域・水系 別に決めて利用する必要があり，この点については，主 としてわが国の主要貯水池群を対象にして地形・地質・ 地被条件などを考慮した regional index の分類を検討 中である。さらに，同一地域・水系内における個々の貯 水池については，確率事象としての土砂収支に対する支
配水文量の評価決定が重要であり，たとえば，貯水池の 堆砂現象を支配する主要水文因子として洪水流量を採用 する場合には，既往洪水流量の時系列的水文統計処理に より，堆砂現象を対象にしたいわゆる支配流量を決める べきである。この点に関しても，その支配流量が年洪水 流量の何\%の超過確率洪水流量に相当するかなどについ て多くの観測資料によって検討中である。

\section{6. あとがき}

貯水池の管理・保全の面から最も重要な問題として堆 砂現象による諸障害があげられているが，その対策面は もちろんのこと合理的なダム計画面から貯水池の堆砂量 や堆砂分布などの予知が必要となってくる。このような 観点から, 内外 768 個の主要貯水池に関する既往堆砂実 測資料を収集し，堆砂現象の実態を客観的に正しく把握 するため巨視的な解析を行ない, 経験的に貯水池の設計 堆砂量などを推算する方法について検討した。

その結果を要約すると, わが国主要ダム群は経過年数 $Y=60 \sim 70$ 年以下のもので全堆砂率 $R_{s}>50 \%$ のもの が約 $12 \% ， R_{s}>80 \%$ に達し本来の機能を丳失してい るものが約 $7 \%$ に達しており, 諸外国の主要ダム群に比 較して平均年堆砂率 $r_{s}$ からみた埋没速度が一般に高 い。環境・立地の面から地域的には中部地方のダム群が 最も埋没速度高く, 堆砂給源からみると台風災害の頻発 する四国地方のダム群が最も比堆砂量が大きく評価され る。さらに水系別，貯水池相別にも埋没危険性が異なっ ているが, 個々のダムでは比堆砂量が $q_{s}=10^{3}\left(\mathrm{~m}^{3} / \mathrm{km}^{2} /\right.$ year）の order を示して, 計画当初の 設計比堆砂量を 超過しているものもみられ，このような貯水池の堆砂問 題がダム計画の前途に大きな障壁となりつつある。

普遍性のある経験的な貯水池堆砂量の推定を目標にし て， $C / F$ 比， $C / I$ 比または $Q / F$ 比などの情報因子を平 均年堆砂率 $r_{s}$ や平均比堆砂量 $q_{s}$ と関連うけた巨視的 な解析を行ない，それぞれ式 (3), (4), (17), (18),(20) なる経験式を得た。これらの結果は，国際的な広範囲に わたる地域全体としての貯水池堆砂実態を総括的につか み得る点で一般性が認められるから，ダム計画に際し堆 砂量の推定に供用できる。

しかし, 流域内個々のダム堆砂の適正な推定には, さ らに地域的特性を示す regional index の加味が必要で ある。また，このような堆砂災害は，その給源となる流 域の土砂生産・流出が長期間の連続的現象を示す場合よ り,むしろ不連続的で偶発的な異常現象を示す場合に主 として支配されるものであるから，この点個々のダム堆 砂量の適正評価には，さらに水文時系列特性などと関連 ゔけた時系列的取り扱いが必要である。 
最後に, 経験式の算出には, 情報量が多いため, 香川 大学計算センターの電子計算機を用いたことを付記す る。

1）吉良八郎：貯水池の堆砂に関する研究 (1), 香川県立農 科大学学術報告, Vol. 17, No. 1, 1955, pp. 15 26.

2）吉良八郎：堆砂宰による貯水池寿命の 推定, 土地改良, Vol. 10, No. 12, 1960, pp. 1 22.

3）吉良八郎: 貯水池の堆砂関する 水理学的研究, 香川大 学農学部紀要, No. 12, 1963, pp. 1 191.

4）通産省公益事業局水力課：昭和 $38 \cdot 40 \cdot 42 \cdot 43$ 年度貯水池 土砂堆積状況表, 発電水力, No. 75, 1965, No. 87, 1967, No. 100, 1969, No. 105, 1970.

5) 通産省公益事業局水力課編著: 日本発電用高堰堤 要覧, 発電水力協会, 1954, pp. 1 404.

6）田中治雄：わが国における貯水池築造に関する応用地学 的研究, 電力中研・技街研究所報告, 士木 No. 57011, 1957, pp. $173 \sim 254$.

7）建設省河川局利水課 : 河川嬷堤の 堆砂量について，資源 調査会土地部会資料, No. 114, 1950.

8) Khosla A.N. : Silting of reservoirs, Central Board of Irrigation and Power, Publication No. 51, India, 1953, pp. 1 206.

9) Wu Chian-Min : Sediment problems of watershed in Taiwan, Quarterly Journal of Chinese Forestry, Vol. 1, No. 3, 1968, pp. 20 80.

10) Borland W.M. and Miller C.R. : Distribution of sediment in large reservoirs, Proc. A.S.C.E., Vol. 84, No. HY-2, 1958, pp. 1 18.

11) Renfro G.M. and Moore C.M. : Sedimentation studies in the Western Gulf States, Proc. A.S.C.E., Vol. 84, No. HY-5, 1958, pp. 1 ij.

12) Rouse H. : Engineering hydraulics, John Wiley and Sons, NewYork, 1958, pp. 772.

13) Jenkins J.E., Moak C.E. and Okun D.A. : Sedimentation in reservoirs in the southeast, Proc. A.S.C.E., Vol. 86, No. SA-4, 1960, pp. 55 70.

14) Moore C.M., Wood W.I. and Renfro G.W. : Trap efficiency of reservoirs, debris basins, and debris dams, Proc. A.S.C.E., Vol. 86, No. HY-2, 1960, pp. $69 \sim 87$.

15) Fox C.S., Cassidy W.C., Lane E.W., Maddok T. \& Borland W.M., Duquesnois H., Raynaud J.P., Drouhin, Mallet \& Pacquant, Reminieras \& G. Braudeau G., Ehrmann P., Rao K.L. \& Raghavachari S., Hoon R.C., Nizery A. \& Rousselier M., Holecek

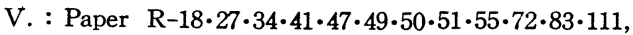
Ques. No. 14, IVth Congress on Large Dams, 1951.

16) Eakin H.M. : Silting of reservoirs, U.S. Dept. of Agriculture Tech. Bull. 524, 1939.

17) Hartung F. : Ursache und Verhütung der Stauraumverlandung bei Talsperren, Die Wasserwirtshaft, 491, 1959.

18) Brown C.B. : Discussion of "Sedimentation in reservoirs" by Witzig, Proc. A.S.C.E., Vol. 69, No. 6, 1943, pp. 793 815, 1493 1499.

19) Brune G.M. : Trap efficiency in reservoirs, Transactions, A.G.U., Vol. 34, No. 3, 1953, pp. 407 418.

20) Summary on reservoir sedimentation surveys made in the United States through 1953, U.S.I.A.C. on Water Resources, Subcomm. on Sedimentation, Sedimentation Bull. 6, August, 1957, Handbook of Applied
Hydrology, McGraw-Hill, 1964, pp. 17, 28 29.

21) Murota A. : Some proposals of the stochastic method of forecasting for deposits in reservirs, Proc. I.H.S., Fort Collins, Colorado, U.S.A., Vol. 1, 1967, pp. 376 $\sim 383$.

22）前川忠夫・脇谷 武 : かんがい用貯水池相に 関する研究 (堆砂による貯水池形態の変移), 香川大学農学部学術報 告, Vol. 13, No. 1, 1961, pp. 73 80.

23) Dendy F.E. : Sedimentation in the Nation's reservoirs, Journal of Soil and Water Conservation, JulyAugust, 1968, pp. 135 137.

24）前川忠夫：かえがい用貯水池相に関する研究（貯水池の 環境について), 香川大学農学部学術報告, Vol. 8, No. 1, 1956, pp. 36 43.

25）関西電力建設部: 黑部第 4 貯水池の推定堆砂量について, ダム設計資料, No. 4, 1957.

26）京大防災研究所 富山地区災害 調査グループ：富山地区災 害調査, 昭和 44 年 8 月水災害の総合的調查研究報告, 1970, pp. 39 93.

27) Witzig B.J. : Sedimentation in reservoirs, Proc. A. S.C.E., Vol. 69 , No. 6, 1963, pp. $793 \sim 815$.

28）鶴見一之: 貯水池堆砂量の一算定法, 土木学会誌, Vol. 39, No. 3, 1954, pp. 143 145.

29) Flaxman E.M. and Hobba R.L. : Some factors affecting rates of sedimentation in the Columbia River Basin, Trans. A.G.U., Vol. 36, No. 4, 1955, pp. 293 $\sim 303$.

30) Gottschalk L.C. and Brune G.M. : Sediment design criteria for the Missouri Loess Hills, U.S. Soil Conservation Serv., SCS-TP-97, 1950.

31) Woodburn R. : Sediment production in small watershed, Agr. Eng., Vol. 36, No. 7, 1955, pp. 467 473.

32) 吉良八郎 : 堆砂防除に関与る土砂水理学的研究 (III), 農 業土木学会論文集, No. 21,1967, pp. 42 49.

33）吉良八郎：かんがい用貯水池の堆砂に関する研究（III, IV), 香川大学 農学部学術報告, Vol. 8, No. 1, 1956, pp. $65 \sim 75,76 \sim 79$.

34）吉良八郎：かんがい用貯水池の堆砂に関する研究 (V,VI, $\mathrm{VII}, \mathrm{VII}, \mathrm{IX}, \mathrm{X})$, 貯水池における密度流について, 香川大 学農学部学術報告, Vol. 9, No. 1, 1957, pp. 11 17, Vol. 9, No. 2, 1957, pp. 79 93, Vol. 9, No. 3, 1958, pp. $171 \sim 194$, Vol. 10, No. 1, 1959, pp. 51 73, Vol. 10, No. 2, 1959, pp. 125 136, Vol. 11, 1959, pp. 111 $\sim 137$.

35）吉良八郎：貯水池の 堆砂分布予知法について，農業土木 研究, Vol. 26, No. 7, 1959, pp. 58 60.

36）吉良八郎・横瀬広司：貯水池の堆砂儿関する実験 ( I , II, III), 農業土木研究別册, No. 1, 1960, pp. 55〜61, 62〜 $68,68 \sim 74$.

37）吉良八郎・玉井佐一：特性曲線法による 貯水池の 堆砂機 㯍に関する解析, 農業土木研究, Vol. 28, No. 6, 1961, pp. $17 \sim 24$.

38）吉良八郎：貯水池に打ける 池水の流動と 水質分布につい $\tau$, 香川大学農学部学術報告, Vo. 12 , No. 1, 1960, pp. $52 \sim 63$.

39）吉良八郎：貯水池の堆砂面勾配について, 香川大学農学 部学術報告, Vol. 13, No. 1, 1961, pp. 87 96.

40) 吉良八郎ほか：堆砂防除に関する土砂水理学的研究（I, II , IV), 香川大学農学部学術報告, Vol. 17, No. 1, 1965, pp. 50 66, Vol. 20, No. 2, 1969, pp. 135 166, 農業土木学会論文集, No. 15, 1966, pp. 21 30.

41) Kira $H$. : Studies on sediments in irrigation channels, Sixth Congress International Commission on Irrigation 
and Drainage, New Delhi, Question 20, R-19, 1966, pp. 20-435 20-447.

42) Kira H. : Problems concerning the improvement of sand elimination facilities for the Amagawa Derivation Channel, Seventh Congress, I.C.I.D., Mexico, Question 24, R-23, 1969, pp. 24-333 24-352.

43）吉良八郎・佐々木 孝: 特殊転倒ゲートの排砂特性につい $\tau$, 農業土木学会誌, Vol. 36, No. 9, 1968, pp.15 22.

44）吉良八郎・佐々木 孝:天川頭首工改修に伴う水理模型実
験報告 (3), 天川導水路中の土砂吐工に関する実験, 1968, pp. $1 \sim 31$.

45）山口岩介: 山地災害, 水経済年報; 1960 年版, 水利科学 研究所編, 1960, pp. 403 412.

46）矢野勝正：土砂災害とその対策, 水工学シリーズ, 67-06, 土木学会水理委員会, 1967, pp. 1 37.

47）石外 宏: 貯水池の堆砂量について, 発電水力, No. 86, 1967, pp. 28 36.

(1971.1.14 · 受付) 